\title{
Iron and thrombosis
}

\author{
Massimo Franchini • Giovanni Targher • \\ Martina Montagnana • Giuseppe Lippi
}

Received: 30 August 2007 / Accepted: 11 November 2007 / Published online: 8 December 2007

(C) Springer-Verlag 2007

\begin{abstract}
Although essential for cell physiology, an increase or depletion of body iron has harmful effects on health. Apart from iron deficiency anemia and iron overload-related organ tissue damage, there are increasing evidences that body iron status is implicated in atherosclerotic cardiovascular diseases. The hypothesis formulated in 1981 that iron depletion may protect against cardiovascular events is intriguing and has generated a significant debate in the last two decades. Indeed, to study this phenomenon, several investigators have tried to design appropriate experimental and clinical studies and to identify useful biochemical and genetic markers of iron status. The results of the literature on the effect of iron deficiency and overload on vascular health are critically reviewed in this study from a pathogenic and clinical point of view.
\end{abstract}

\footnotetext{
M. Franchini

Servizio di Immunoematologia e Trasfusione, Centro Emofilia, Azienda Ospedaliera di Verona,

Verona, Italy

G. Targher

Sezione di Endocrinologia e Malattie del Metabolismo, Dipartimento di Scienze Biomediche e Chirurgiche, Università di Verona,

Verona, Italy

M. Montagnana $\cdot$ G. Lippi

Istituto di Chimica e Microscopia Clinica, Dipartimento di

Scienze Biomediche e Morfologiche, Università di Verona,

Verona, Italy

M. Franchini $(\triangle)$

Servizio di Immunoematologia e Trasfusione, Centro Emofilia, Ospedale Policlinico,

Piazzale Ludovico Scuro,

37134 Verona, Italy

e-mail: mfranchini@univr.it
}

Keywords Iron · Thrombosis · Anemia

\section{Introduction}

Iron is an essential nutrient for living cells because of its role as a cofactor for enzymes in the mitochondrial respiration chain, in the DNA synthesis, and being the central molecule for binding and transport of oxygen by hemoglobin and myoglobin.

While the lack of iron leads to growth arrest and anemia, an increased accumulation of this metal is associated with toxic radical formation and progressive tissue damage. It is interesting to note that both iron deficiency and excess have been associated with an increased risk of developing thromboembolic events [1-7].

This review will analyze, from a clinical and pathogenic point of view, the existing literature data on the relationship between iron and arterial and venous thrombosis.

\section{Iron deficiency and thrombosis}

There are several reports in the literature on thrombotic complications in iron-deficient children and adults [8-26]. Secondary thrombocytosis has been implicated in many cases. Indeed, iron deficiency is a cause of reactive thrombocytosis, usually mild [27]. For instance, within a study group of children with iron deficiency, reactive thrombocytosis was found in up to one-third of them [28].

Nagai et al. [29] reported a case of severe iron deficiency with marked thrombocytosis $\left(1,020 \times 10^{9} / 1\right)$ that was complicated by central retinal vein occlusion. By contrast, Kinoshita et al. [26] described two cases of cerebral venous sinus thrombosis associated with iron deficiency and 
normal platelet count. Hartfield et al. [13] reported six children with iron deficiency who developed an ischemic stroke or venous thrombosis. Four of them had a concomitant thrombocytosis. In a prospective case-control study, Stolz et al. [30] found that severe anemia, along with thrombophilia and hypercholesterolemia, were independent risk factors for cerebral venous thrombosis.

The mechanisms causing reactive thrombocytosis in iron deficiency anemia are not completely understood. Iron is an important regulator of thrombopoiesis [31, 32]. Whereas normal iron levels are required to prevent thrombocytosis by inhibiting thrombopoiesis, a minimum amount of iron is required to maintain platelet production. Thus, while thrombocytosis is usually associated with a mild iron deficiency and is the result of a lack of inhibition of thrombopoiesis, a severe defect of this metal may be accompanied by thrombocytopenia. However, studies on thrombopoietic cytokines failed to show any effect on reactive thrombocytosis in iron deficiency [27]. For instance, Akan et al. [33] assayed the serum levels of thrombopoietin, erythropoietin, leukemia inhibitor factor, IL-6, and IL-11 in patients with iron-deficient anemia with or without elevated platelet count. Only erythropoietin level was elevated, correlated with thrombocytosis, and decreased with iron replacement. The other cytokines remained unchanged after therapy, suggesting that they probably do not play any significant role in iron deficiencyassociated reactive thrombocytosis. Recently, Bilic and Bilic reported that the amino acid sequence homology of thrombopoietin and erythropoietin may explain the thrombocytosis in children with iron deficiency anemia [34]. By contrast, two other reports suggested that the relationship between iron deficiency and reactive thrombocytosis is more complex than a mere consequence of a crossreactivity between erythropoietin and thrombopoietin [35, 36]. In addition to the increased thrombotic risk associated with high platelet count, other authors have suggested that the decrease in antioxidant defense in iron deficiency anemia may cause increased oxidant stress, which in turn may result in a tendency toward platelet aggregation [37]. Thus, the abnormal platelet count and function observed in iron deficiency anemia could act synergistically to promote thrombus formation, especially in the setting of an underlying atherosclerotic disease [23].

However, as not all cases of iron-related thrombotic events occur in patients with concomitant high platelet count $[13,26]$, other pathogenic mechanisms have been proposed in these last years. Thus, iron deficiency may contribute to a hypercoagulable state by affecting blood flow patterns within the vessels because of reduced deformability and increased viscosity of microcytic red blood cells [13]. Furthermore, anemic hypoxia secondary to iron deficiency could precipitate situations of increased metabolic stress (i.e., infections) in particularly vulnerable areas of the brain supplied by end arteries, such as the basal ganglia, thalamus, and hypothalamus [38]. This phenomenon could explain the association between iron-deficient anemia and reversible focal deficits and stroke found by some authors $[1,13,39,40]$.

\section{Iron overload and thrombosis}

Accumulation of iron in excess of physiologic requirements has been implicated in the development of several chronic illnesses, including cardiovascular diseases [7]. As previously reported, iron is a prooxidant cofactor associated with an increased production of hydroxyl radical in cardiovascular tissues and increased progression of atherosclerosis in experimental models [41-44]. Indeed, in an experimental mouse thrombosis model, a moderate iron overload markedly accelerated thrombus formation, impaired vasoreactivity, and enhanced the production of reactive oxygen species and systemic markers of oxidative stress [41]. It is interesting to note that the administration of DL-cysteine, a reactive oxygen species scavenger, completely abrogated the iron load-induced thrombus formation thus corroborating the hypothesis that iron accelerates thrombosis through a prooxidant mechanism. Similarly, laboratory investigations have demonstrated iron-dependent generation of reactive oxygen species in endothelial cell cultures and increased aortic atherosclerosis in the apolipoprotein Edeficient mice and cholesterol-fed rabbits with increased iron intake [42-44].

The research in this field has focused on the evaluation of the impact of iron depletion and iron overload on cardiovascular outcomes. Sullivan first postulated in 1981 the "iron hypothesis" by which the chronic iron depletion has a protective effect against ischemic heart disease and may account for the reduced risk of cardiovascular events in menstruating women [45-47]. Basing on these observations, some investigators have studied the effect of serial blood donations on the coronary heart disease risk, but their results were inconsistent [48-53]. However, an important support to the hypothesis of a potential link between blood donation and reduced cardiovascular risk came from a recent study conducted by Zheng et al. [54] who found that high-frequency blood donors had decreased serum ferritin levels, a marker of body iron stores; decreased serum 3nitrotyrosine levels, a marker of oxidative stress; and greater flow-mediated dilation in the brachial artery, a marker of vascular function. It is interesting to note that in a clinical study, the iron chelation with deferoxamine improved endothelial function in patients with coronary artery disease [55]. By contrast, in a multicenter, randomized controlled trial (the iron $[\mathrm{Fe}]$ and Atherosclerosis 
Study [FeAST]) on 1,277 patients with symptomatic peripheral arterial disease, the reduction of body iron stores by phlebotomy did not significantly decrease all-cause mortality or death plus nonfatal myocardial infarction and stroke [56]. Similarly, in a prospective analysis of the second National Health and Nutrition Examination Study (NHANES II), Sempos et al. [57] observed either no association (in Caucasian men) or a possible nonsignificant increased risk (in Caucasian women) of cardiovascular or coronary heart disease death among individuals with low ferritin concentrations.

On the other hand, the association between biochemical markers of body iron load and the risk of developing cardiovascular disease have been investigated by several studies [7, 58-72]. In the Kuopio Ischemic Heart Disease Risk Factor Study (KIHD), serum ferritin levels were found to be one of the strongest risk factors for acute myocardial infarction among Finnish men [61]. Similar findings were reported from a Canadian study [65] that observed an increased risk of myocardial infarction among subjects in the highest serum iron category and from the Bruneck study [64] in which a positive association between serum ferritin levels and ultrasound measures of progression of carotid atherosclerosis over a 5-year follow-up period was found. A relationship between serum ferritin levels and carotid atherosclerosis was also identified by a recent study conducted by Wolff et al. [71]. Haidari et al. [60] observed a significant correlation between serum ferritin levels and risk of coronary heart disease in male Iranian patients. However, a number of epidemiological studies did not find an association between iron status and coronary artery disease [61, 69, 70, 72]. For instance, Bozzini et al. [61] found that the mean serum ferritin concentrations were slightly higher in coronary heart disease patients than in controls, but this difference disappeared after adjusting for sex and C-reactive protein.

The 1996 discovery of $H F E$ gene mutations responsible for most cases of hereditary hemochromatosis has led to the use of genetic markers of iron overload, which are not influenced by external factors such as inflammation, in epidemiologic studies. Thus, several authors have investigated in recent years the relationship between $\mathrm{C} 282 \mathrm{Y}$ and H63D mutations in the HFE gene and the risk of cardiovascular diseases [73-88]. Three prospective population-based studies have reported an association between heterozygotes and vascular events [75-77].

The first study was from a subgroup of the original Finnish KIHD cohort [75]. Of 68 individuals, 8 (11.8\%) were diagnosed with acute myocardial infarction, and of 1,150 noncoronary heart disease participants, 77 (6.7\%)

Table 1 Summary of the most important studies on the association between HFE gene mutations (C282Y and H63D) and the risk of cardiovascular diseases

\begin{tabular}{|c|c|c|c|}
\hline Authors [reference] & Study design & Population & Results \\
\hline $\begin{array}{l}\text { Tuomainen et al. } \\
\text { [75] }\end{array}$ & Prospective & 1,150 individuals & $\begin{array}{l}\text { C282Y heterozygosity is associated with a } 2.3 \mathrm{RR} \\
\text { for AMI compared with noncarriers }\end{array}$ \\
\hline $\begin{array}{l}\text { Roest et al. } \\
{[76]}\end{array}$ & Prospective & 12,239 postmenopausal women & $\begin{array}{l}\mathrm{C} 282 \mathrm{Y} \text { heterozygosity is associated with a } 1.6 \mathrm{RR} \\
\text { for TCD compared with noncarriers }\end{array}$ \\
\hline $\begin{array}{l}\text { Rasmussen et al. } \\
\text { [77] }\end{array}$ & Prospective & 243 CHD cases and 535 controls & $\begin{array}{l}\text { C282Y heterozygosity is associated with a } 2.7 \mathrm{RR} \\
\text { for CHT compared with noncarriers }\end{array}$ \\
\hline $\begin{array}{l}\text { Gaenzer et al. } \\
\text { [78] }\end{array}$ & Case-control & $41 \mathrm{C} 282 \mathrm{Y} / \mathrm{C} 282 \mathrm{Y}$ cases and 51 controls & $\begin{array}{l}\text { C282Y homozygosity is associated with impaired } \\
\text { endothelial function }\end{array}$ \\
\hline $\begin{array}{l}\text { Bozzini et al. } \\
{[61]}\end{array}$ & Case-control & $546 \mathrm{CHD}$ cases and 303 controls & $\mathrm{C} 282 \mathrm{Y}$ mutation is not associated with $\mathrm{CHD}$ \\
\hline $\begin{array}{l}\text { Rossi et al. } \\
{[80]}\end{array}$ & Case-control & 1,098 subjects & $\begin{array}{l}\mathrm{C} 282 \mathrm{Y} \text { mutation is not a risk factor for } \\
\text { asymptomatic carotid atherosclerosis }\end{array}$ \\
\hline $\begin{array}{l}\text { Franco et al. } \\
{[81]}\end{array}$ & Case-control & $256 \mathrm{CHD}$ cases and 272 controls & $\begin{array}{l}\text { C282Y and H63D mutations are not associated } \\
\text { with CHD }\end{array}$ \\
\hline \multirow[t]{2}{*}{$\begin{array}{l}\text { Ellervik et al. } \\
\text { [79] }\end{array}$} & Prospective & 9,178 individuals & $\begin{array}{l}\text { C282Y and H63D mutations are not associated } \\
\text { with CHD }\end{array}$ \\
\hline & Case-control & $\begin{array}{l}\text { 2,441 CHD and } 1,113 \text { AMI cases } \\
\text { vs } 8,080 \text { controls }\end{array}$ & $\begin{array}{l}\text { C282Y and H63D mutations are not associated } \\
\text { with CHD }\end{array}$ \\
\hline $\begin{array}{l}\text { Gunn et al. } \\
{[86]}\end{array}$ & Case-control & $482 \mathrm{CHD}$ cases and 1,104 controls & $\mathrm{C} 282 \mathrm{Y}$ mutation is not associated with $\mathrm{CHD}$ \\
\hline $\begin{array}{l}\text { Campbell et al. } \\
\text { [88] }\end{array}$ & Case-control & 924 AMI cases and 1,029 controls & $\mathrm{C} 282 \mathrm{Y}$ mutation is not associated with $\mathrm{CHD}$ \\
\hline $\begin{array}{l}\text { Yunker et al. } \\
\text { [89] }\end{array}$ & Case-control & 907 individuals & $\begin{array}{l}\text { HFE genotype is not related to brachial endothelia } \\
\text { function and carotid atherosclerosis }\end{array}$ \\
\hline
\end{tabular}

$A M I$ : acute myocardial infarction, $C H D$ : coronary heart disease, $R R$ : relative risk, $T C D$ : total cardiovascular death 
were carriers of $\mathrm{C} 282 \mathrm{Y}$. The crude relative risk of myocardial infarction was $2.0(95 \% \mathrm{CI}=0.9-4.1)$ and the adjusted relative risk was $2.3(95 \% \mathrm{CI}=1.1-4.8)$. In a cohort of 12,239 Dutch postmenopausal women, the $\mathrm{C} 282 \mathrm{Y}$ carrier status was assessed among 531 women who died of cardiovascular disease and 555 randomly selected women who did not die of cardiovascular disease [76]. This study reported a relative risk of $1.6(95 \% \mathrm{CI}=1.1-2.4)$ for total cardiovascular death. Finally, in the United States Atherosclerosis Risk in Communities (ARIC) study [77], a C282Y carrier frequency of $9.9 \%$ among 243 coronary heart disease cases and $6.1 \%$ among 535 controls was reported. The crude relative risk of coronary heart disease associated with $\mathrm{C} 282 \mathrm{Y}$ carrier status was $1.6(95 \% \mathrm{CI}=0.9-$ 3.0) and was $2.7(95 \% \mathrm{CI}=1.2-6.0)$ after being controlled for other risk factors. To support of these findings, Gaenzer et al. [78] found an association between increased iron stores and impaired endothelial function (measured as endothelium-dependent dilation and intima-media thickness) in patients homozygous for $\mathrm{C} 282 \mathrm{Y}$ mutation. Irondepletion therapy normalized the endothelial function in such patients thus reducing the increased risk of cardiovascular events.

However, the majority of the studies disagreed with these results [61, 79-89]. Indeed, Bozzini et al. [61] found a similar rate of carriers of $\mathrm{C} 282 \mathrm{Y}$ mutation among patients with coronary atherosclerotic disease and controls. In a case-control study on 1,098 subjects, Rossi et al. [80] found that $\mathrm{C} 282 \mathrm{Y}$ mutation was not a predictor of asymptomatic carotid atherosclerosis. Franco et al. [81] reported that the $H F E$ genes were not associated with coronary or peripheral atherosclerosis in patients aged less than 50 years. Similarly, in the West of Scotland Coronary Prevention Study (WOSCOPS), Gunn et al. [86] found that the presence of a $\mathrm{C} 282 \mathrm{Y}$ mutation in the $H F E$ gene did not predict the occurrence of coronary events over a mean follow-up of 4.9 years. It is interesting to note that Yunker et al. [89] analyzed the relationship between biochemical and genetic markers of iron overload and carotid intimamedia thickness and brachial flow-mediated vasodilation by high-resolution ultrasound in 907 males, but neither ferritin nor hemochromatosis genotype were related to brachial endothelial function and carotid atherosclerosis. In addition, a recent large study from Denmark found no increased risk of coronary heart disease among carriers of the C282Y mutation or individuals who had compound heterozygosity for the C282Y and H63D mutations [79].

Other investigation have focused on the association between genetic markers of iron overload and idiopathic dilated cardiomyopathy and stroke, but their results were conflicting [90-94].

Finally, some authors have suggested that HFE C282Y could interact with other predisposing factors for venous thromboembolism, such as factor V Leiden, thus exacerbating their prothrombotic effect [95].

Table 1 summarizes the most important studies on the association between genetic markers of iron overload and cardiovascular diseases.

\section{Conclusions}

It is interesting to note that although with different pathogenic mechanisms, both iron deficiency and overload have been associated with an increased thrombotic risk in experimental and clinical studies.

However, several aspects need to be still elucidated in this field. In particular, large prospective controlled trials are needed to elucidate the role of genetic markers of iron stores and the impact of long-term iron depletion on morbidity and mortality from cardiovascular events.

\section{References}

1. Gillum RF, Sempos CT, Makuc DM, Looker AC, Chien CY, Ingram DD (1996) Serum transferrin saturation, stroke incidence, and mortality in women and men. The NHANES I Epidemiologic Followup Study. National Health and Nutrition Examination Survey. Am J Epidemiol 144:59-68

2. Keung YK, Owen J (2004) Iron deficiency and thrombosis: literature review. Clin Appl Thromb Hemost 10:387-391

3. Kirkham FJ (2003) Stroke and cerebrovascular disease in childhood. Curr Open Pediatr 13:350-359

4. Dame C, Sutor AH (2003) Primary and secondary thrombocytosis in childhood. Br J Haematol 129:165-177

5. Chan AK, Deveber G, Monagle P, Brooker LA, Massicotte PM (2003) Venous thrombosis in children. J Thromb Haemost $1: 1443-1455$

6. Ma J, Stampfer MJ (2002) Body iron stores and coronary heart disease. Clin Chem 48:601-603

7. Sempos CT (2002) Do body iron stores increase the risk of developing coronary heart disease? Am J Clin Nutr 76:501-503

8. Schloesser LL, Kipp MA, Wenzel FJ (1965) Thrombocytosis in iron-deficiency anemia. J Lab Clin Med 66:107-114

9. Ready WK, Lowry NJ (1989) Anemia causing cerebral infarction in a child. CMAJ 140:303-304

10. Belman AL, Roque CT, Ancona R, Anand AK, Davis RP (1990) Cerebral venous thrombosis in a child with iron deficiency anemia and thrombocytosis. Stroke 21:488-493

11. Bruggers CS, Ware R, Altman AJ, Rourk MH, Vedanarayanan V, Chaffee S (1990) Reversible focal neurologic deficits in severe iron deficiency anemia. J Pediatr 117:430-432

12. Matsuoka Y, Hayasaka S, Yamada K (1996) Incomplete occlusion of central retinal artery in a girl with iron deficiency anemia. Ophthalmologica 210:358-360

13. Hartfield DS, Lowry NJ, Keene DL, Yager JY (1997) Iron deficiency: a cause of stroke in infants and children. Pediatr Neurol 16:50-53

14. Swann IL, Kendra JR (2000) Severe iron deficiency anaemia and stroke. Clin Lab Haematol 22:221-223 
15. Meena AK, Naidu KS, Murthy JM (2000) Cortical sinovenous thrombosis in a child with nephrotic syndrome and iron deficiency anaemia. Neurol India 48:292-294

16. Kirkham TH, Wrigley PF, Holt JM (1971) Central retinal vein occlusion complicating iron deficiency anaemia. Br J Ophthalmol 55:777-780

17. Knizley H Jr, Noyes WD (1972) Iron deficiency anemia, papilledema, thrombocytosis, and transient hemiparesis. Arch Intern Med 129:483-486

18. Alexander MB (1983) Iron deficiency anemia, thrombocytosis, and cerebrovascular accident. South Med J 76:662-663

19. Heller DS, Pervez NK, Kleinerman J (1988) Fatal cerebrovascular thrombosis in a young woman: an unusual complication associated with hypochromic anemia and thrombocytosis following surgery. Mt Sinai J Med 55:318-320

20. Aoki N, Sakai T (1989) Cerebral sinus thrombosis in patients with severe iron deficiency anaemia due to myoma uteri. Acta Neurochir (Wien) 97:131-134

21. Stehle G, Buss J, Heene DL (1991) Noninfectious thrombosis of the superior sagittal sinus in a patient with iron deficiency anemia. Stroke 22:414

22. Saxena VK, Brands C, Crols R, Moens E, Marien P, de Deyn PP (1993) Multiple cerebral infarctions in a young patient with secondary thrombocythemia due to iron deficiency anemia. Acta Neurol (Napoli) 15:297-302

23. Akins PT, Glenn S, Nemeth PM, Derdeyn CP (1996) Carotid artery thrombus associated with severe iron-deficiency anemia and thrombocytosis. Stroke 27:1002-1005

24. Kacer B, Hattenbach LO, Horle S, Scharrer I, Kroll P, Koch F (2001) Central retinal vein occlusion and nonarteritic ischemic optic neuropathy in 2 patients with mild iron deficiency anemia. Ophthalmologica 215:128-131

25. Benedict SL, Bonkowsky JL, Thompson JA, Van Orman CB, Boyer RS, Bale JF Jr, Filloux FM (2004) Cerebral sinovenous thrombosis in children: another reason to treat iron deficiency anemia. J Child Neurol 19:526-531

26. Kinoshita Y, Taniura S, Shishido H, Nojima T, Kamitani H, Watanebe T (2006) Cerebral venous sinus thrombosis associated with iron deficiency: two case reports. Neurol Med Chir (Tokyo) 46:589-593

27. Dan K (2005) Thrombocytosis in iron deficiency anemia. Intern Med 44:1025-1026

28. Dickeroff R, von Ruecker A (1991) Thrombozytose im Kindesalter. Differentialdiagnose und klinische Bedeutung. Paediatrische Praxis 41:25-28

29. Nagai T, Komatsu N, Sakata Y, Miura Y, Ozawa K (2005) Iron deficiency anemia with marked thrombocytosis complicated by central retinal vein occlusion. Intern Med 44:10901092

30. Stolz E, Valdueza JM, Grebe M, Schlachetzki F, Schmitt E, Madlener K, Rahimi A, Kempkes-Matthes B, Blaes F, Gerriets T, Kaps M (2007) Anemia as a risk factor for cerebral venous thrombosis? An old hypothesis revisited: results of a prospective study. J Neurol 254:729-734

31. Karpatkin S, Garg S, Freedman M (1974) Role of iron as a regulator of thrombopoiesis. Am J Med 57:521-525

32. Beguin Y (1999) Erythropoietin and platelet production. Haematologica 84:541-547

33. Akan H, Guven N, Aydogdu I, Arat M, Beksac M, Dalva K (2000) Thrombopoietic cytokines in patients with iron deficiency anemia with or without thrombocytosis. Acta Haematol 103: 152156

34. Bilic E, Bilic E (2003) Amino acid sequence homology of thrombopoietin and erythropoietin may explain thrombocytosis in children with iron deficiency anemia. J Pediatr Hematol Oncol 25:675-676
35. Racke F (2003) EPO and TPO sequences do not explain thrombocytosis in iron deficiency anemia. J Pediatr Hematol Oncol 25:919

36. Geddis AE, Kaushansky K (2003) Cross-reactivity between erythropoietin and thrombopoietin at the level of Mpl does not account for the thrombocytosis seen in iron deficiency. J Pediatr Hematol Oncol 25:919-920

37. Tekin D, Yavuzer S, Tekin M, Akar N, Cin S (2001) Possible effects of antioxidant status on increased platelet aggregation in childhood iron-deficiency anemia. Pediatr Int 43:74-77

38. Balci K, Utku U, Asil T, Buyukkoyuncu N (2007) Deep cerebral vein thrombosis associated with iron deficiency anaemia in adults. J Clin Neurosci 14:181-184

39. Young RS, Rannels DE, Hilmo A, Gerson JM, Goodrich D (1983) Severe anemia in childhood presenting as transient ischemic attacks. Stroke 14:622-623

40. Hart RG, Kanter MG (1990) Hematologic disorders and ischemic stroke. A selective review. Stroke 21:1111-1121

41. Day SM, Duquaine D, Mundada LV, Menon RG, Khan BV, Rajagopalan S, Fay WP (2003) Chronic iron administration increases vascular oxidative stress and accelerates arterial thrombosis. Circulation 107:2601-2606

42. Zweier JL, Broderick R, Kuppusamy P, Thompson-Gorman S, Lutty GA (1994) Determination of the mechanism of free radical generation in human aortic endothelial cells exposed to anoxia and reoxygenation. J Biol Chem 26:24156-24162

43. Araujo JA, Romano EL, Brito BE, Parthe V, Romano M, Bracho M, Montano RF, Cardier J (1995) Iron overload augments the development of atherosclerotic lesions in rabbits. Arterioscler Thromb Vasc Biol 15:1172-1180

44. Lee TS, Shiao MS, Pan CC, Chau LY (1999) Iron-deficient diet reduces atherosclerotic lesions in apoE-deficient mice. Circulation 99:1222-1229

45. Sullivan JL (1981) Iron and the sex difference in heart disease risk. Lancet 1:1293-1294

46. Sullivan JL (1989) The iron paradigm of ischemic heart disease. Am Heart J 117:1177-1188

47. Sullivan JL (2003) Are menstruating women protected from heart disease because of, or in spite of, estrogen? Relevance to the iron hypothesis. Am Heart J 145:190-194

48. Meyers DG (2000) The iron hypothesis: does iron play a role in atherosclerosis? Transfusion 40:1023-1029

49. Meyers DG, Strickland D, Maloley PA, Seburg JK, Wilson JE, McManus BF (1997) Possible association of a reduction in cardiovascular events with blood donation. Heart 78:188-193

50. Meyers DG, Jensen KC, Menitove JE (2002) A historical cohort study of the effect of lowering body iron through blood donation on incident cardiac events. Transfusion 42:1135-1139

51. Tuomainen TP, Salonen R, Nyyssonen K, Salonen JT (1997) Cohort study of relation between donating blood and risk of myocardial infarction in 2682 men in eastern Finland. BMJ 314:793-794

52. Ascherio A, Rimm EB, Giovannucci E, Willett WC, Stampfer MJ (2001) Blood donations and risk of coronary heart disease in men. Circulation 103:52-57

53. Salonen JT, Tuomainen TP, Salonen R, Lakka TA, Nyyssonen K (1998) Donation of blood is associated with reduced risk of myocardial infarction. The Kuopio Ischaemic Heart Disease Risk Factor Study. Am J Epidemiol 148:445-451

54. Zheng H, Cable R, Spencer B, Votto N, Katz SD (2005) Iron stores and vascular function in voluntary blood donors. Arterioscler Thromb Vasc Biol 25:1577-1583

55. Duffy SJ, Biegelsen ES, Holbrook M, Russell JD, Gokce N, Keaney JF Jr, Vita JA (2001) Iron chelation improves endothelial function in patients with coronary artery disease. Circulation 103:2799-2804 
56. Zacharski LR, Chow BK, Howes PS, Shamayeva G, Baron JA, Dalman RL, Malenka DJ, Ozaki CK, Lavori PW (2007) Reduction of iron stores and cardiovascular outcomes in patients with peripheral arterial disease: a randomized controlled trial. JAMA 297:603-610

57. Sempos CT, Looker AC, Gillum RE, McGee DL, Vuong CV, Johnson CL (2000) Serum ferritin and death from all causes and cardiovascular disease: the NHANES II Mortality Study. National Health and Nutrition Examination Study. Ann Epidemiol 10:441448

58. van der A DL, Peeters PH, Grobbee DE, Marx JJ, van der Schouw YT (2005) Dietary haem iron and coronary heart disease in women. Eur Heart J 26:257-262

59. Ramakrishna G, Rooke TW, Cooper LT (2003) Iron and peripheral arterial disease: revisiting the iron hypothesis in a different light. Vasc Med 8:203-210

60. Haidari M, Javadi E, Sanati A, Hajilooi M, Ghanbili J (2001) Association of increased ferritin with premature coronary stenosis in men. Clin Chem 47:1666-1672

61. Bozzini C, Girelli D, Tinazzi E, Olivieri O, Stranieri C, Bassi A, Trabetti E, Faccini G, Pignatti PF, Corrocher R (2002) Biochemical and genetic markers of iron status and the risk of coronary artery disease: an angiography-based study. Clin Chem 48:622628

62. Salonen JT, Nyyssonen K, Korpela H, Tuomilehto J, Seppanen R, Salonen R (1992) High stored iron levels are associated with excess risk of myocardial infarction in eastern Finnish men. Circulation 86:803-811

63. Salonen JT, Nyyssonen K, Salonen R (1994) Body iron stores and the risk of coronary heart disease. N Engl J Med 331:1159

64. Kiechl S, Willeit J, Egger G, Poewe W, Oberhollenzer F (1997) Body iron stores and the risk of carotid atherosclerosis: prospective results from the Bruneck study. Circulation 96: 3300-3307

65. Morrison HI, Semenciw RM, Mao Y, Wigle DT (1994) Serum iron and risk of fatal acute myocardial infarction. Epidemiology $5: 243-246$

66. Gillum RF (1997) Body iron stores and atherosclerosis. Circulation 96:3261-3263

67. de Valk B, Marx JJ (1999) Iron, atherosclerosis, and ischemic heart disease. Arch Intern Med 159:1542-1548

68. Niederau C (2000) Iron overload and atherosclerosis. Hepatology 32:672-674

69. Danesh J, Appleby P (1999) Coronary heart disease and iron status: meta-analyses of prospective studies. Circulation 99:852-854

70. Sempos CT, Looker AC, Gillum RF, Makuc DM (1994) Body iron stores and the risk of coronary heart disease. N Engl J Med 330:1119-1124

71. Wolff B, Volzke H, Ludemann J, Robinson D, Vogelgesang D, Staudt A, Kessler C, Dahm JB, John U, Felix SB (2004) Association between high serum ferritin levels and carotid atherosclerosis in the study of health in Pomerania (SHIP). Stroke 35:453-457

72. Auer J, Rammer M, Berent R, Weber T, Lassnig E, Eber B (2002) Body iron stores and coronary atherosclerosis assessed by coronary angiography. Nutr Metab Cardiovasc Dis 12:285-290

73. Hu FB (2007) The iron-heart hypothesis. JAMA 297:639-641

74. Sullivan JL (1999) Iron and the genetics of cardiovascular disease. Circulation 100:1260-1263

75. Tuomainen TP, Kontula K, Nyyssonen K, Lakka TA, Helio T, Salonen JT (1999) Increased risk of acute myocardial infarction in carriers of the hemochromatosis gene Cys282Tyr mutation: a prospective cohort study in men in eastern Finland. Circulation 100:1274-1279

76. Roest M, van der Schouw YT, de Valk B, Marx JJ, Tempelman MJ, de Groot PG, Sixma JJ, Banga JD (1999) Heterozygosity for a hereditary hemochromatosis gene is associated with cardiovascular death in women. Circulation 100:1268-1273

77. Rasmussen ML, Folsom AR, Catellier DJ, Tsai MY, Garg U, Eckfeldt JH (2001) A prospective study of coronary heart disease and the hemochromatosis gene (HFE) $\mathrm{C} 282 \mathrm{Y}$ mutation: the Atherosclerosis Risk in Communities (ARIC) study. Atherosclerosis 154:739-746

78. Gaenzer H, Marschang P, Sturm W, Neumayr G, Vogel W, Patsch J, Weiss G (2002) Association between increased iron stores and impaired endothelial function in patients with hereditary hemochromatosis. JACC 40:2189-2194

79. Ellervik C, Tybjaerg-Hansen A, Grande P, Appleyard M, Nordestgaard BG (2005) Hereditary hemochromatosis and risk of ischemic heart disease: a prospective study and a case-control study. Circulation 112:185-193

80. Rossi E, McQuillan BM, Hung J, Thompson PL, Kuek C, Beilby JP (2000) Serum ferritin and C282Y mutation of the hemochromatosis gene as predictors of asymptomatic carotid atherosclerosis in a community population. Stroke 31:3015-3020

81. Franco RF, Zago MA, Trip MD, ten Cate H, van den Ende A, Prins MH, Kastelein JJ, Reitsma PH (1998) Prevalence of hereditary haemochromatosis in premature atherosclerotic vascular disease. Br J Haematol 102:1172-1175

82. Battiloro E, Ombres D, Pascale E, D, 'Ambrosio E, Verna R, Arca M (2000) Haemochromatosis gene mutations and risk of coronary artery disease. Eur J Hum Genet 8:389-392

83. Hetet G, Elbaz A, Gariepy J, Nicaud V, Arveiler D, Morrison C, Kee F, Evans A, Simon A, Amarenco P, Cambien F, Grandchamp B (2001) Association studies between haemochromatosis gene mutations and the risk of cardiovascular diseases. Eur J Clin Investig 31:382-388

84. Claeys D, Walting M, Julmy F, Wuillemin WA, Meyer BJ (2002) Haemochromatosis mutations and ferritin in myocardial infarction: a case-control study. Eur J Clin Investig 32(Suppl. 1): 3-8

85. Nassar BA, Zayed EM, Title LM, O, 'Neill BJ, Bata IR, Kirkland SA, Dunn J, Dempsey GI, Tan MH, Johnstone DE (1998) Relation of HFE gene mutations, high iron stores and early onset coronary artery disease. Can J Cardiol 14:215-220

86. Gunn IR, Maxwell FK, Gaffney D, McMahon AD, Packard CJ (2004) Haemochromatosis gene mutations and risk of coronary heart disease: a west of Scotland coronary prevention study (WOSCOPS) substudy. Heart 90:304-306

87. Surber R, Sigusch HH, Kuehnert H, Figulla HR (2003) Haemochromatosis (HFE) gene $\mathrm{C} 282 \mathrm{Y}$ mutation and the risk of coronary artery disease and myocardial infarction: a study in 1279 patients undergoing coronary angiography. J Med Genet 40: e58

88. Campbell S, George DK, Robb SD, Spooner R, McDonagh TA, Dargie HJ, Mills PR (2003) The prevalence of haemochromatosis gene mutations in the West of Scotland and their relation to ischaemic heart disease. Heart 89:1023-1026

89. Yunker LM, Parboosingh JS, Conradson HE, Faris P, Bridge PJ, Buithieu J, Title LM, Charbonneau F, Verma S, Lonn EM, Anderson TJ (2006) The effect of iron status on vascular health. Vasc Med 11:85-91

90. Mahon NG, Coonar AS, Jeffery S, Coccolo F, Akiyu J, Zal B, Houlston R, Levin GE, Baboonian C, McKenna WJ (2000) Haemochromatosis gene mutations in idiopathic dilated cardiomyopathy. Heart 84:541-547

91. Hannuksela J, Leppilampi M, Peuhkurinen K, Karkkainen S, Saastamoinen E, Helio T, Kaartinen M, Nieminen MS, Nieminen P, Parkkila S (2005) Hereditary hemochromatosis gene (HFE) mutations $\mathrm{C} 282 \mathrm{Y}, \mathrm{H} 63 \mathrm{D}$ and $\mathrm{S} 65 \mathrm{C}$ in patients with idiopathic dilated cardiomyopathy. Eur J Heart Fail 7:103-108 
92. Hetet G, Grandchamp B, Bouchier C, Nicaud V, Tiret L, Roizes G, Desnos M, Schwartz K, Dorent R, Komajda M (2001) Idiopathic dilated cardiomyopathy: lack of association with haemochromatosis gene in the CARDIGENE study. CARDIGENE Group Heart 86:702-703

93. Njajou OT, Hollander M, Koudstaal PJ, Hofman A, Witteman JC, Breteler MM, van Duijn CM (2002) Mutations in the hemochromatosis gene (HFE) and stroke. Stroke 23:2363-2366
94. Hruskovicova H, Milanez T, Kobal J, Potisk KP, Petrovic D, Peterlin B (2005) Hemochromatosis-causing mutations C282Y and H63D are not risk factors for atherothrombotic cerebral infarction. Med Sci Monit 11: BR248-BR252

95. MacLean RM, Feeney GP, Bowley SJ, Bowen DJ, Worwood M, Collins PW (1999) Factor V Leiden and the common haemochromatosis mutation HFE C282Y: is there an association in familial venous thromboembolic disease? Br J Haematol 107:210-212 